\title{
The Crisis of the Ethics of Audit Profession: Collapse of Enron Company and the Lessons Learned
}

\author{
Hasen Mohamed A. Albeksh \\ Department of Business Administration, Kastamonu University, Kastamonu, Turkey \\ Email: hasenalbeksh@gmail.com
}

How to cite this paper: Albeksh, H.M.A. (2016) The Crisis of the Ethics of Audit Profession: Collapse of Enron Company and the Lessons Learned. Open Access Library Journal, 3: e3205.

http://dx.doi.org/10.4236/oalib.1103205

Received: November 5, 2016

Accepted: November 26, 2016

Published: November 30, 2016

Copyright (C) 2016 by author and Open Access Library Inc.

This work is licensed under the Creative Commons Attribution International

License (CC BY 4.0).

http://creativecommons.org/licenses/by/4.0/

\begin{abstract}
The aim of this study is to describe and analyze the reason of collapse of the biggest energy company, the American company Enron, which is considered one of the events that has a great effect on the profession of accounting and auditing. This study focuses in the ethics, which is considered as a preventer and a conservator of the occurrence of collapses and financial scandals. The descriptive analysis approach was adopted, which depended on the inductive methodology by inducting the studies and researches which aimed to explain and analyze the reasons of the collapse of Enron company and knowing the lessons learnt from it and the methods to avoid financial scandals like this. We are going to summarize some lessons that can be learnt to avoid the same fate of Enron and regain trust of the financial markets as well as both professions of accounting and auditing. This study is divided into an introduction and four parts and a conclusion. The results find that there are many reasons of the collapse of Enron company, the most important is, the administration of the company made inflation of the profits ostensibly up to billion dollars in the year before the company's collapse. Moreover, the internal audit in the company failed in the ethical and financial aspects as a result of continuous deception, greed, bribery, speculation and fraud.
\end{abstract}

Subject Areas

Accounting

Keywords

Ethics, Audit Profession, Collapse of Enron

\section{Introduction}

Auditing plays an important role in developing and enhancing the economical companies 
and international works. Depending on the opinion of the auditors of accounts about the just of the financial lists, the main goal of reviewing is to add trust on the information included in the financial lists. These information are considered as the green light for decision makers in their investments and knowing the expected revenues, costs and risks which participate in enhancing the investments whether on the level of the individual or the level of total income, as discussed by Al-Khaddash et al. (2013) [1].

The profession of accounts' auditing faced many important challenges in the last ten years after the collapse of Enron company in 2 December 2001 followed by six out of ten biggest bankrupts of companies which occured in this period, as discussed by Mansouri et al. (2009) [2]. Committment of the rules of professional behaviours and ethics of those who work in auditing is considered as a recognition of the responsibility related to the profession of accounting and auditing in general for the society, clients and their colleagues. These ethical principles and rules are not new invention. Islam pioneered establishing these principles and worked on rooting them since the birth of this religion, such as truthful testimony, avoiding perjury, incorruptibility, honesty, sticking by the truth, justice and controlling desires, do not betray and be faithful in performing his job, this is the ethics which Islam came up with, as discussed by AlMoataz (2008) [3].

In this context, this paper aims to study reasons of the collapse of Enron company by explanation and analysis, whence describes the background of this great fall of this giant company, and how this fall was related to the loss of many ethics and behaviours which should be characterized in each of audit office and the parties inside the company, such as the administration of the company, the board and the members of the audit committee. Taken into consideration that what happened in a certain country might happen in other place, if there were available factors which led to it. We should not forget the fate of joint stock companies in some countries related to the acute decrease in its value in the markets, these companies were imposed to more losses during the lack and weakness of transparency and accountability between companies on one hand, and all other benefitted parties on the other.

The researcher followed the descriptive analysis approach which relied primarily on the inductive approach through extrapolation of studies and research to explain and analyze the causes of the collapse of Enron Corporation, and analyze the background and nature and the reasons of that to conclude the ethics and lessons from that collapse, even the ideas, relations and the scientific and practical aspects which were included in these researches and studies were analyzed. The method used in this study is considered one of the descriptive studies, which are characterized by giving the researcher an actual and clear theoretical basis in the analyzing and interpreting aspects.

We summarize lessons that can be learned in order to restore confidence in the financial markets and prevent another Enron. The paper is divided to four segments. The first segment examines the ethical rules study for the profession of auditing and the ethics in Islam and the theoretical framework and approach employed support this pa- 
per where it examines the case of the collapse of Enron company by details, and how that fall was relevant to the lack of many professional and work ethics and good manners by great responsible people in the company and the members of the board, moreover the involvement of one of the biggest auditing offices "Arthur Anderson" which was responsible for auditing the accounts of the company in many wrong practices and behavior. The second segment discusses the lessons learned from Enron's collapse. The third segment discusses the previous studies and its evaluation. Finally, the fourth segment discusses the governance of companies and how to manage and guide companies by inspecting performance through which the levels of work ethics can be improved, and improving the levels of control inside the companies by developing the regulation of governance of companies which leads to enhancement of control, accountability and disclosure in companies. Then the researcher summarizes the results, recommendations and concludes in this paper.

\section{The Theoretical Framework and Literature Review}

\subsection{The Ethical Rules of Auditing Profession}

Ethics are an overall topic for all aspects of insurance of human life and development of human and social relationships which have become more complicated, which create new needs with the appearance of different professions. Ethics lie in the personal behavior represented in the personality based on public and intangible rights and responsibilities. They can be divided into three sections:

1) Responsiblity for others in their personal lives.

2) Responsible person about a special profession and others.

3) Organization responsible for the internal and external environments, as discussed by Kaveh et al. (2014) [4].

According to Pasşu (2012), ethics can be defined as the set of principles which give a value to ethics and they are the ethics behavior necessary for a society to work in an organized way. In addition, the need to ethics is very important enough to different ethical values to be included in laws. "AICPA", American Institute of Certified Public Accountants, provides the general rules of professional behavior and the assigned behavioral standards with practical application, as discussed by Pasşu (2012) [5].

Shaw (2008) suggested that "ethics begins with each individual, with their inner feelings, which subsequently translate into ethical behavior. Individuals learn to adapt ethical principles through their socialization process, life experiences and critical reflection, together with the explicit and implicit standard of culture", as discussed by Shaw (2008) [6].

Studies point to that existence of moral behavior is necessary to establish a society, and different work fields including accounts' reviewing. Providing moral behavior is a necessary need to gain the trust of services providers who have integrity and objectivity in addition to the trust in the provided financial statements, as discussed by Al qtaish, et al. (2014) [7]. 


\subsection{Ethics in Islam}

God said, addressing the Messenger Muhammad, Peace Be upon Him "Surely, you (Prophet Muhammad) are of a great morality" (Surat, Al-Qalam, verse 4). To complete the best and the highest ethics Prophet Muhammad Peace Be upon Him, Said in the meaning "I have been sent to complete the best highest ethics" (narrated by Al-Bukhari, p. 273). He also said in the meaning "The best of you the one with high ethics" (Narrated by Al-Nawawi, p. 263, http://www.e-quran.com) [8].

This indicates the importance of ethics and its significant role in the dissemination of Islam, which has been disseminated in the South East Asia region, Indonesia and Malaysia, by high ethics of Muslim Tradesmen who opened the hearts and markets of the land, as discussed by Al qtaish et al. (2014) [7].

The auditor should work to reach the Ihsan degree and mastering of work, not only mere doing his professional duties. This needs him to be academically qualified, experienced, who have a good knowledge as stated in the interpretation of the words of $\mathrm{Al}$ lah (Yusuf) said: "Set me over the storehouses of the land; I will indeed guard them with full knowledge" (as a minister of finance in Egypt, in place of the first minister who was dead at that time) (Surat, Yusuf, verse 55)

(http://www.dar-us-salam.com/TheNobleQuran [9]).

The difference between ethics and values is clear in philosophy; ethics include the good and the bad, while values are only about the good. Therefore, ethics are represented in a set of moral principles such as trust, honesty, uprightness, integrity, and job proficiency, as discussed by Jamieson \& Gellermann (2014) [10], to which accounts' auditors should be committed. It is represented in the professional behavior rules and professional standards, as discussed by Rong (2011) [11].

\subsection{The Collapse of Enron Company and the Loss of Profession and Work Ethics}

Accounting profession and all work section went through a great crisis which can be expressed by saying ethical crisis clearly because of the control of avarice and narrow private interests on the largest part of this section in different countries in the world between 1990 until the autumn of 2001. The internationally famous Enron company in the work section was known to be creative and depends on technology, as discussed by Pavel and Encontro (2012) [12].

The collapse of Enron company at the end of 2001 is considered the most important and the last company which fell as a result to many factors, the most important ones are not applying or the absence of professional and work ethics. The giant company fell with assets that reach 64.4 billion dollars, which is the biggest bankruptcy to an American company internationally. After hearing 56 witnesses in 15 weeks of trial sessions in Huston city in the state of Texas, the jury, formed by eight men and four women, decided unanimously that two of executive managers in Ernon company and they are, Jeffery Skilling and Kenneth Lay were guilty in many accusations in cases related to corruption and conspiracy and lying as well about the financial difficulties of the company, 
as discussed by Al-Moataz (2008) [3]. In May 2006, Skilling was found guilty in 18 accusations out of 28 . If he was accused for all of them, the period of his prison will reach 275 years result of fraud and conspiracy and one count of insider trading. On the other hand, Lay was found guilty in six accusations related to trickery and conspiracy. Finally, the judges charged Jeffery Skilling to be prison him for 24 years and four months and pay 45 million dollars in restitution. The judge who stated the judgment while reading the judgement decision, "Crimes like this deserve to be punished severly". Skilling brought before the court alone after his partner Kenneth Lay had died because of a heart attack in July 2006, as discussed by Robinson (2012) [13].

The price of the share in Enron company has developed from less than seven dollars in the 90 s reaching 90 dollars in the middle of 2000, but it has lost its value surprisingly to reach 90 cents by the end of 2001. It was a tragic end to the shareholders in that giant company when they were watching the assets of their company decreasing from thousands of millions of dollars into nothing in a short period of time, as discussed by Benston \& Hartgraves (2002) [14].

In 2000, Enron company announced for clients about a deal with a stream for movies on the internet using frequency range presentation, it also has developed a market for energy to walk side by side with the technological revolution in the early 20th century, as discussed by Anna Pha (2010) [15]. As many Western countries, especially Germany, the most significant investment in the field of renewable energy, as initial policy. In particular, the Scandinavian countries, Britain, the Netherlands and Spain, as discussed by Benli Tahir et al. [16], and Enron published about 53 million dollars as profits on the basis of the predictions of the deal. The awards for executers were paid according to this number, despite of the loss. The price of the share continued to increase after the fail of this deal, most of the executive managers in Enron sold many of financial bills. The general picture of the company was improving while the executive managers sold about 1 billion dollars of their personal financial bills. Jeffery Skilling and Kenneth Lay were accused of saling about 200 - 300 million dollars of the company's shares gradually, as discussed by Anna Pha (2010) [15]. In August 2000, Enron company announced that it is going to provide a report about the financial bonds and speculation in the most modern program for expansion in the new markets. The shares of Enron were circulated as 90 dollars/share, but this was a desperate move, although it was called the most creative company by Fortune Magazine as discussed by Gordon (2002) [17]. The magazine published a title of "The Outstanding Works Named as Enron, the most creative American Company" which was number 1 in the quality of administration and number 2 of the talented employees among all other American companies, as discussed by Anna Pha (2010) [15].

Benli et al. (2013) clarified that brand enabled a business enterprise to ease its product differentiation. In addition to the actual physical differences of the product or service, brands also help to differentiate the subjective image that the consumers created in their minds. For the realization of a successful product development process, through all the steps, from idea to the presentation of the product to the market, full support of 
senior management, as discussed by Benli Tahir et al. (2013) [18].

The annual report of Enron company for 2002 (dated on April 2001), drew a bright picture for the rapid increase of profits and the great opportunities in the future: the sales and revenues have also increase in the United States from 13.2 billion dollars in 1996 into more than 100 billion dollars in 2002. The income before counting the interest and taxes which increased into $72 \%$ in the previous year reached 2.3 billion dollars. The total revenues of the company to the shareholders were $89 \%$ in 2000 as discussed by Anna Pha (2010) [15].

Al-Moataz (2008) [3]. Stated that it seemed that some members of auditing committees thought they were above human motives when the member has personal connections with the company. For example, the members of the committee were taking big amounts, each member took 380,619 dollars cash or as shared in 2001, these big amounts with no doubt affected the independence and neutralism of the auditing committee. The problem of conflict in interests between shareholders and the administration allowed privacy for the part which controls the information, which is the administration, to have the correct information alone.

In this aspect, Jennings (2002) gave many examples about the cases of conflict between the interests of the administration and the shareholders of the company. Although some cases were not considered as violation of independence rules, it encouraged the administration and the members of the audit committee to satisfy each other in order to maintain the personal interests by staying in their positions. Their personal interests which they tried to maintain were the clearest definition of conflict of interests and obvious effect on the ethical principles of human nature. There is a clear tendency in human beings to be faithful to whom provided a favor to it, as discussed by Jennings (2002) [19].

About this, Tonge et al. (2003) mentioned that the board of directors spent 15 minutes only to review some suspicious deals which led to the increase of profits reaching imaginary numbers, as discussed by Tonge et al. (2003) [20]. The international auditing office (Arthur Anderson) as well which was one of the five biggest offices then, which was paid 25 million dollars as wages for auditing the accounts of Enron in 1999, it also was paid 23 million dollars to do consultant works for this company in the same year, which is another evidence that the auditor's independence and neutralism were threatened if he did both tasks. According to Andersen, a significant but undetermined" number of documents and electronic files related to Enron were destroyed. The other five offices decided, after this incident, to stop combining these two services for the same client, which was decided after that in the law Sarbans-Oxley Act of the year 2002. It was described as the most important and effective legislations in governing the companies and financial disclosure and practicing auditing profession since the American law of circulating financial papers during the thirties of the previous century, as discussed by Moncarz et al. (2006) [21].

Arthur Anderson Office used to also do another task other than the previous two tasks, which is the internal auditing for the same company, that participated largly in 
the occurrence of those financial scandals as discussed by Tonge et al. (2003) [20]. Thus, Arthur Anderson Company failed to give a truthful and just opinion because of the weakness of the professional and ethics standards, this led to its collapse and it went out of competition. What happened with Arthur Anderson company brings to the mind the subject of Expectation Gap between the practical reality which may be painful and the hopes and ambitions of other categories. The head of the international auditing office declared that there was a mistake done in the aspect of Professional Judgment about one of the companies related to Enron which was not listed in the united financial lists of Enron and its following companies, so the office partner and the responsible of auditing the financial lists of Enron tended to set his orders to his assistants by throwing the papers and the internal and external normal and electronic correspondence related to this process which considered unacceptable behavior. This scandal happened for Arthur Anderson company is considered the biggest in accounting profession, the second oldest professions in the world. Arthur Anderson company shared with Enron company its offices and tearing the free-charge papers, it treated hundreds of pounds of the company's documents for 52 million dollars a year, as discussed by Bryce (2002) [22].

One of the things was found in the research related to the case of Enron company is that some of the employees who were working inside Enron Company in its administration and the members of the board including three of the members of auditing committee had sold 17.3 million shares costing 1.1 billion dollars, was discovered which did not include the salaries, big rewards and other cash payments which were paid for them during the period of administrating the company. At the same time, when the company was led to its death and immediately before the issuance of the financial lists that uncovered the ugly truth for the shareholders in the company. Surprisingly, the head of the board of Enron company "Andy Fastow" declared before few weeks of the company's collapse that the situation of the company is strong, and he said "I am sure that the future of the company is bright and its development is certain", this shows that the administration of the company tended to hide the losses and commitments of the company and their attempts to give a false picture of the true consequences of the company and its financial situation, as discussed by Al-Moataz (2008) [3].

Knowing that measure the impact of the stock market index is given to the New York Stock Exchange weekly closing values. Although much of the impact of the political expectations and the impact of political developments in these indicators is known to exist. Week not given by looking at the value of the index,as discussed by Tolga Ulusoy (2010) [23].

Pha (2010) clarified that within 12 months Enron had collapsed and announced its bankruptcy behind a shining façade, and it put the main elements of Capitalism: greed, bribery, corruption, deception, intrusion, speculation, internal circulation, fraud, patronage, evasion from paying taxes, destroying environment, violations of human rights, exploitation, stealing the dues of workers, job loss, usage of state's devices against workers, intimate relationships with the government, manipulating, and monopoliza- 
tion of the market prices as discussed by Anna Pha (2010) [15].

Erdoğan (2002) sees that to help prevent errors in the future is to improve and build standards that the profession control, people and organizations in the Financial Management Development-Notify them about the future of their investments in the company's of business men and valid in other words, a review of the financial control system, will be directed to become a reliable and consistent to determine deviations it should be by the way, using the audit techniques as discussed by Murat Erdoğan (2002) [24].

More than 20,000 employees had lost their jobs, and the average of their rewards and medical insurance was 4500 dollars. In 2001, the employees of Enron have lost more than a billion dollars in pension funds, the retired people lost 2 billion dollars in the pension funds. In 2001 as well, the big executive responsible employees in Enron 116 have spent one million dollars in the financial papers, they have paid 55 million dollars for rewards, as discussed by Robinson (2012) [13].

Al-Moataz (2008) stated that surprisingly three of the six members of auditing committee in Enron company had about 100 thousand shares valued in about 7.5 million dollars, thus some writers wondered "Did greed blind the committee and they did not discover the violations in the financial lists?" Indeed, some of the managers in the company in addition to the three members of the auditing committee have sold 17.3 million shares valued by 1.1 billion dollars during the issuance of the financial lists which uncovered the big disaster.

Moreover, Enron Company issued shares for one company in order to obtain bonds which led to inflation of assets and the rights of shareholders about 1.2 billion dollars without having actual cash flows as a result of wrong accounting treatments that led to considering some information to be Off Balance Sheet Items. The administration of Enron Company declared of the inflation of profits in the amount of 586 million dollars and hiding the debts of 2.6 billion dollars. Therefore, investors and financial analysts lost confidence in the company and many questions have raised about the truth of the companies that Enron company deals with and the nature of that connections. This led to the appearance of more undeclared losses and commitments which participated in the occurrence of the collapse as discussed by Al-Moataz (2008) [3].

Most of the members of the board in Enron Company have spent more than 14 years in the membership whence they used to enjoy the best of everything. One of Enron's airplanes used to take them from wherever they are to the place where the meeting is held, which spared much time that might be spent in airports and the possibility of losing luggage and the late flights. The meetings of the company were always held in the most respectful and luxurious places and they were paid the highest salaries as discussed by Pavel and Encontro (2012) [12]. Each member gains 50 thousand dollars a year for his/ her membership and an amount of 1250 dollars for each meeting, the average of the received money was 87,500 dollars cash and as free shares in Enron for working for two weeks without making much trouble. Some mentioned that if the non-executive manager were not independent they would not dare to bite the hand which feeds them, as discussed by Bryce (2002) [22]. 
Many surprising paradoxes showed how the people who should have protected the rights of the shareholders and other parties were involved in delivering huge rewards from the company, and they used to have big shares of the company's shares as well which they have sold in a suspicious way before the announcement of the fall of the company with high prices, as if they were expecting the acute collapse of the value of the company's shares. The following tables state some of these paradoxes:

Table 1 shows the statement of some of the financial behaviors done by great responsible in Enron Company:

We can note from the previous table how the big responsible people in the company behaved towards its shares by using the internal information that gave them clues about the collapse of the company, then they sold its shares with very high prices while it was about to collapse, this reminds us with the case of Information Asymmetry between the people inside and outside the companies which is a raised question in many studies as discussed by Al-Moataz (2008) [3]. The organization of economic cooperation and development pointed to the governance of companies (OECD, 2015) in its principles that "the process of circulating shares depending on internal information should be prohibited, and processes of exchange aiming to achieve the interests of people related to the company should be prohibited as well", as discussed by OECD $(2015,2008)$ [25]

Table 2 shows the situation of some of the company members that can be theoretically classified by the tools of governance system in companies and the statement of the indicators for the people responsible for governance of companies and what was discovered later.

Table 1. The statement of some of the financial behaviors done by great responsible in Enron Company.

\begin{tabular}{|c|c|}
\hline Position & Behavior \\
\hline Financial manager & Sold more than a million share \\
\hline A member of compensation committee & Sold more than 1.7 million shares in 2000 \\
\hline $\begin{array}{l}\text { The head of rewards for executive } \\
\text { managers committee }\end{array}$ & Sold 2 million shares in May 2001 \\
\hline The head of the rewards for auditing office committee & Sold 841 thousand shares \\
\hline The head of company's policies committee & $\begin{array}{l}\text { Obtained } 12 \text { million dollars as a reward in } 2000 \text {, } \\
\text { he also speculates some shares with a value of } \\
123 \text { millions, then obtained a reward with the } \\
\text { value of } 10.6 \text { millions in } 2001 \text { and sold shares } \\
\text { with a value of } 50 \text { millions in the same year }\end{array}$ \\
\hline $\begin{array}{l}\text { The vice president of executive managers and the } \\
\text { financial responsible in the company }\end{array}$ & $\begin{array}{c}\text { Obtained } 3 \text { million dollars as a monthly reward } \\
\text { in January and February 2001, he also collected } \\
30 \text { million as a partner in one of the companies } \\
\text { related to the company }\end{array}$ \\
\hline A financial responsible in the company & $\begin{array}{l}\text { Sold shares in the company with a value of } 268 \\
\text { million with a price of } 72 \text { dollars per share }\end{array}$ \\
\hline
\end{tabular}

Source: Al-Moataz (2008) [3]. 
Table 2. The situation of some of the company members that can be theoretically classified by the tools of governance system in companies and the statement of the indicators for the people responsible for governance of companies and what was discovered later.

\begin{tabular}{|c|c|}
\hline Indicators of governance system in companies & Characteristics in Enron \\
\hline Communication with investors & Lying and cheating \\
\hline $\begin{array}{l}\text { The relationship with official legislators of systems } \\
\text { and privilages }\end{array}$ & Very strong relationship \\
\hline $\begin{array}{c}\text { The number of independent non-executive } \\
\text { managers }\end{array}$ & Doubted independence \\
\hline $\begin{array}{l}\text { Existence of ethical charter in the company of } \\
\text { auditing committee }\end{array}$ & $\begin{array}{l}\text { Stated and undesired, uneffective and } \\
\text { there is a conflict in interests }\end{array}$ \\
\hline Compensation committee & $\begin{array}{l}\text { A claim was raised against the head of the } \\
\text { committee for having deals inside the company }\end{array}$ \\
\hline $\begin{array}{l}\text { Separation between the professions of internal and } \\
\text { external auditing }\end{array}$ & $\begin{array}{l}\text { It is not existed because Arthur } \\
\text { Anderson office combined between them }\end{array}$ \\
\hline Existence of a system prohibit conflict of interests & Not existed \\
\hline $\begin{array}{l}\text { Existence of a clear definition for the tasks and } \\
\text { responsibilities of managers }\end{array}$ & $\begin{array}{l}\text { It was put under table and faild } \\
\text { to accomplish its tasks }\end{array}$ \\
\hline $\begin{array}{l}\text { Non-executive managers doing clear tasks in the } \\
\text { company }\end{array}$ & Minimum level \\
\hline
\end{tabular}

Source: Al-Moataz (2008) [3].

One of the results and effects of the collapse of the giant company is that; the big international auditing office, which was then one of the biggest five offices, went out of competition after proving that it was guilty in obstructing justice and deceptive it. The rush of the five auditing offices to give consultant services increasingly had a great impact on their independence.

The financial scandals, which appeared in many companies wether in the United States or others, made people afraid of the role the administration boards provide as well as the auditing committees in inspecting and following up the whole financial process in order to protect the companies from cheating and manipulating, that is why it was called governance of companies, companies were under observation in acute criticism of the inspection procedures followed in companies,as discussed by Al-Moataz (2008) [3].

On July 25, 2002, Congress passed the Sarbanes-Oxley Act, or SOX was signed in order to encourage the trust in the companies that are publically known. After the scandal of Enron, By that day, stock market indices of large capitalization stocks had fallen 40 percent over the 30 months. The Sarbanes-Oxley legislation was designed to fix auditing companies of U.S. and supervision, regulate auditing, the Public Company Accounting Oversight Board and the accounting practices and preparing the required reports briefly. The legislation created new incentives for firms to spend money on internal controls, above and beyond the increases in audit costs that would have happened 
after the corporate scandals of the early 2000s and according to the position of the higher board of education law was appointed to many reformations to enhance the responsibility of companies, enhance the financial disclosure, fighting fraud in companies and accounting as discussed by Mcclain (2013) [26] and John C. (2007) [27].

The changes included the introduction of the Public Company Accounting Oversight Board (also known as PCAOB to supervise on the professional activities in auditing accounts and the auditing of public companies, reaffirming the requirements for companies to maintain effective internal controls, and requiring the auditors to attest to the effectiveness of these changes. These changes were seismic and felt by all parties involved in the capital markets, especially the accounting and auditing professions to prohibit the occurrence of another Arthur Anderson case in the future. Some people deem that the cost of executing standards higher than Sarbanes-Oxley Act is very expensive for small companies. The total effect of the legislations are considered effective. The trust of investors was regained temporarily, the predictions about security was similar to speculating goods in the case of Enron. The increasing American financial system in 2008 and the resulted policies do not require more accurate accounting principles and more organization to the companies of inspection to provide the processes of accounting auditing for these companies as discussed by Shakespeare C. (2008) [28].

\section{Previous Studies}

Sanğlar \& Kandemîr (2007) clarified in their study "Enron Event: Accounting Tricks Is System Error?", the elements of economical crime in the collapse of Enron company, and they are:

1) The organizers of these crimes are the head of the board, the general manager and the financial affairs manager.

2) The style of the crime is to hide the debts and create resources and increase the tended inflation aiming to create entities of special purpose.

3) Guiding the crime and investors to the profitability of the company and the debts to decieve them out of reality.

4) Using the lack of auditing jobs for companies.

5) The results of registering bankruptcy, shareholders and the market opened more than 20 cases of loss valued more than 60 billion dollars as discussed by Sanğlar \& Kandemîr (2007) [29].

While Zulauf \& Grierson (2011) pointed in their study to that there are three items that should have alerted investors much sooner:

1) The great reliance on "energy trading" for profits. These trading activities formed for about $80 \%$ of Enron's earnings.

2) The acceleration of great, unrealized, non-cash gains into their current earnings even though it was hugely likely that none of these gains would actually materialize.

3) The famous partnerships and own purpose vehicles, which hid debt and were controlled by company insiders as discussed by Zulauf \& Grierson (2011) [30]. 
Dharan \& Bufkins (2008) deem in their study "Red Flags in Enron's Reporting of Revenues and Key Financial Measures." That what was uncovered in the late 2001 of the Enron company's effort to hide the assets in entities with special purposes which depends on maintaining a high value of the fragile Enron shares to maintain and exist, this was the cause of the collapse of the company. Investors revealed how the board of the company and the administration failed even in the basic aspects of governance and inspection of companies. The problems in Enron was even bigger because of the method of compensation system and managing performance which participated in a wrong culture, this participated in increasing the focus on the short-term profits. A culture pushed by the fear of increased compensation of deals, usually without caring for the quality of the cash flows or profits and the numbers of account to obtain quicker attachment in a time to maintain a fragile support to the price of Enron company's shares. Thus, the deal makers and the executive managers ensure that they will have big cash rewards and the profits from buying the shares. Although the disaster of Enron happened in history, functional disorder on wide range, interests conflict, collapse of the standards of governance and the practices of the consulting administration to present the purchased had went far from destroying the trust of investors and weakening the validity and affectivity of the performance of judging companies. Until more reformations are executed and enhance the practices of governance for companies, the way to regain the trust of investors and the work of market brokers in accounting, consulting and legal services, banking services, investment counseling, and crediting classification sectors will be difficult as discussed by Dharan et al. (2008) [31].

Benli \& Kizgin (2013) see that the complaints companies can lead to strong relationships with its customers, but not desirable, companies should look at these complaints about reactions to be able to notice the errors and shortcomings. We should believe that the complaints are a valuable source of information for the management of the business and they provide a valuable opportunity to collect and evaluate customer information effectively as discussed by Benli and Kizgin (2013) [32].

The study made by (Al-Qashi, 2005) company pointed to that the collapse of Enron and its editors; Arthur Anderson, was not because of the common international accounting standards or auditing standards, but the professional ethics itself. Enron was not committed in the mechanisms of measurement and disclosure related to companies and assigned objectives, along with the involvement of the auditors of its accounts; Arthur Anderson, by not reporting that and providing clear reports. the investigation uncovered that Arthur Anderson that was used to execute double works, the external auditor of Enron company and the financial consultant, in addition, the auditors of Arthur Anderson representing an internal auditing circle for the company, which means that the auditors were employees not independent from the company of Enron, which led them to follow such immoral behavior. The study made by Abu Hein, 2005 stated that the commitment of the auditors to the known auditing standards and the rules of professional behavior from experts and the positive effect of academically qualified employees on auditing quality. Auditing offices were depending in the quality auditing standards and maintaining 
its independent entity leads to improving the provided services by auditors. A study made by (Issa, 2008) showed that there was a positive relationship between the control of the auditor's performance and the independence, objectivity and integrity of auditors and the qualification, skills and the type of auditor, as discussed by Al-Moataz (2008) [3].

Training on the audit, the whole exercise consists of checking with the academic knowledge of control theory. It is necessary to establish the cause of development and control theory. Courses in auditing, licensing, education and learning in graduate programs, and this is an important issue is related to a large extent on the quality of education and increase efficiency, as discussed by Murat Erdoğan (2012) [33].

\section{Evaluation of the Previous Studies}

Through what the researcher talked about in the previous studies from the collapse of Enron company, its first reason was the professional ethics crisis for auditors, because the collapse of Enron and others was not a result from having violations in the system but in the professional ethics, as well as the great fail of inspection and the principles of governance for companies. The method of solving the problem will not be by rewards and motivating system alone. The case of Enron cannot be seen as only a financial scandal but as a general disease in a corrupted part in the profession, with the strong involvement of the administrators and inspectors in the company. The case of Enron was not rare, many failure cases happened in a lot of companies, including the scandals of General Electric company which some investigations indicators showed that the most important cause of its collapse was the financial and accounting scandals in which the responsible people hid some financial data and information. Losses were covered by reserve and allocations of employees salaries and some of them maintained their profits from the same resource. Therefore, there are many thinking obstacles rooted in the need to overcome it in order to let accounting solve many stock problems for the collapsed companies, including: the common belief that accounting is able to solve all the problems faced while it is a part of justice system in the society. When th ethics of auditors profession were discussed, researchers recommended that there is a necessity of teach ethical values in universities and make courses for auditing companies in the specializations of accounting and administration and others of financial and administrative sciences to reinforce the important role of the ethical principles and the Profession Honesty Charter, to be an effective prevention from falling in cheating, manipulating, embezzlement and betraying trust.

\section{The Lessons Learned from Enron's Collapse}

What are lessons learned from Enron's collapse, and how do we prevent another Enron, and prevent situations greed in companies? Enron leadership failed to protect the interests of investors through the registration of misleading transactions made economic risks for the company, but was transferred losses and commitments to off-balance sheet entities. 
One of the lessons learnt from the collapse of Enron Company and others that the auditors of the accounts shall ask an important question before doing the auditing process, and the question is: what is the type of the company's activity?, the answer of such question will assign the method of achieving the income and the level of risk. The auditors of Arthur Anderson's office were not able to understand the financial lists for such complicated company. These auditors had treated Enron Company since it was a producer and distributor of Gas and they kept on auditing it even after becoming the main merchant of financial bonds and the responsible for the new speculations in the market. Arthur Anderson company did not change these auditors although the developments occurred for Enron company or it did not support them with other experienced auditors, as discussed by Bryce (2002) [22].

One of the morals learnt is: the partners if Arthur Anderson office and the other staff were not trained to adopt Skepticism which they should have adopted, thus they accepted easily the estimations and the directions of the administration in the financial cases and deals as discussed by Benston \& Hartgraves (2002) [14]. Bryce (2002) mentioned that Enron company needed while signing a deal and doing some false accounting practiced to a written opinion from the auditing office to justify those practices, so a meeting was held between both parties and the auditor from Arthur Anderson company was pawned by putting a chair on the door of the meeting room and they declared that they will not open the door until the delivery of the written opinion from the auditor. After some manipulating and justifications and pressures, the auditor agrees on writing a written opinion after that the chair was removed and the auditor was allowed to leave. We could not imagine such meetings to happen before few years of this disaster, because the auditors were looked upon as judges on the companies where they work not biased to them, as discussed by Bryce (2002) [22].

Felo et al. (2002) clarified the reason of the fail of the auditing committee to report the violations in Enron company was the weakness of the regular requirements in this aspect. The study done by some researchers stated that the auditing committee in the company was compatible with the requirements of the bourse of the financial papers and New York's bourse of financial papers and other authorities which indicates that the case is not about laws and regular requirements but an ethical case. There was corporate governance system in Enron company which includes an ethical charter and an auditing committee, yet nothing was real in reality, as discussed by Felo et al. (2002) [34].

The results of the collapse found that academics and people with theoretical backgrounds do not always have applicable background. In the auditing committee of Enron company there were three members who have great scientific level, one of them was a retired accounting teacher, the other obtained professional companionship and the third was a previous head of the lords house in the UK, yet they could not ask a simple question; why there is not enough reserve in spite of these enormous profits of the company through the years? as discussed by Moncarz et al. (2006) [21].

The company management and auditors, banks, analysts, regulators, speculators and 
developers are all responsible standards in this historic collapse. It has been to encourage a culture based on oversized corporate egos that went beyond its original core business and fostered aggressive accounting practices. Enron need for more stringent regulation in several areas indicate. First and foremost, there is a need to corporate governance, accounting standards and auditing standards. And other risks uncertainties that will provide a transparent table reports relating to summarize the lessons that can be learned from the rise and collapse of Enron analyzed in the previous sections.

\section{Corporate Governance}

Corporate governance is the system of rules, practices and processes by which a company is directed and controlled. It strives to balance the interests of the various stakeholders in a company such as shareholders, management, customers, suppliers, financiers, government and the community to provides the framework for attaining a company's objectives, it encompasses practically every sphere of management, from action plans and internal controls to performance measurement and corporate disclosure, as discussed by Gwarzo (2015) [35]. Governments are endeavoring to enhance their maneuverability to eliminate the associated risks by various packages of financial measures, as discussed by Tolga Ulusoy (2011, p. 9087) [36].

As the Organization of Economical Cooperation and Development mentioned a definition for governance of companies, which is the system through which companies are guided and managed, and through which the rights and responsiblities between different parties such as the board, managers and shareholders and others of people with interests are determined. It alo assign the rules and procedures of making decisions about the affairs of the company, as well as assigning structure through which the objectives of the company, the methods of achieving them and mechanisms of inspecting the performance are put.

The effective governance of companies requires a sane legal, organizational and foundational frame that the participators in the market can depend on having private contractual relationships. This frame is usually consisted of governance of companies on the elements of legislation, organization, automatic organizational arrangements, volunteering committments and commercial practices. Countries which aim to execute the principles of inspecting the frame of governance of companies, including the organizational ones, insertion requirements and commercial practices, in order to maintain the enhancement of its participation in the integrity of the market and the economical performance, it is important to take into consideration the interaction and integration between the different elements of the frame of governance of companies and its total ability to enhance the ethical, responsible and transparent practices of governance of companies. This analysi shall be deemed as an important tool in the process of developing an effective frame of governance of companies according to the following:

1) The frame of governance shall be put aiming to affect the macro economical performance and the safety of the market and the motivations which it creates to the participators in the market and enhance transparent markets that work well. 
2) The legal and organizational requirements which affects the practices of the governance of companies shall fit with the supremacy of law and transparency and to be executable.

3) Dividing the responsibilities between different authorities shall be clarified and designed to serve the public interest.

4) Organization of financial market shall support the effective administration.

Inspection: The organizational and executive authorities shall have integrity and the resources to do its duties in a professional and objective way. In addition, the decisions shall be made in appropriate time and they shall be transparent and clear as discussed by $\operatorname{OECD}(2015,2008)$ [25].

\section{Results and Recommendations}

Results: Last but not least, Enron scandal is not just a complex story about accounting and auditing professions only and it is also a story about the people who made this possible. People have made decisions that affected 21,000 employees in Enron, as well as on America as a whole. We see the reason for the fall of Enron by several factors. Through the many topics that we have chosen to present in this paper, we reached the following results:

1) Among the factors that have contributed to raising the balance of Enron and then failure is the manipulation of the financial statements of the company and the overexploitation of the operations of the financial risky assets in addition to raising energy restrictions, it led to the demise of Enron of business market.

2) The administration of the company inflated the profits of the company to reach a billion dollar in the year before the collapse of the company. The internal auditing failed as well ethically and financially as a result of constant deception. Moreover, Arthur Anderson office which was appointed to audit the accounts of the company was doing the internal auditing as well in addition to the fact that it was providing consulting services.

3) The board appointed the task of auditing the deals made by the company to a branch committee inside of the company, and the committee only reviewed those deals quickly. The board has hidden very important information, in case they were known some suitable procedures that could have been made.

4) Enron's case is considered as an important reminder for the important relationship between the internal auditing and the auditing committee. Internal auditors as well as external ones shall report to the auditing committee everything they face instead of reporting them to the administration.

Recommendations:

1) Paying more attention to the subject of the ethics and behaviors of a profession from all official, academic and professional authorities; specializing many seminars and conferences to talk about it.

2) The risks of processes shall be decreased and there shall be a kind of examination.

3) Giving the regulation of governance of companies more attention and amending it 
according to the interest of its issuance in order to protect companies and protect inquiry and other benefitted parties.

\section{References}

[1] Al-Khaddash, H., Al Nawas, R. and Ramadan, A. (2013) Factors Affecting the Quality of Auditing: The Case of Jordanian Commercial Banks. International Journal of Business and Social Science, 4, No. 11.

[2] Mansouri, A., Pirayesh, R. and Salehi, M. (2009) Audit Competence and Audit Quality: Case in Emerging Economy. International Journal of Business and Management, 4, 17. https://doi.org/10.5539/ijbm.v4n2p17

[3] Al-Moataz, E. (2008) The Ethics of Audit Profession and People Who Deal with: Enron Collapse and Learnt Lessons. King Abdulaziz University Journal: Economics and Management, 22, 293-257.

[4] Kaveh. M., Khalili, M., Ghorbani, A. and Soroush, M. (2014) Professional Ethics in Accounting and Auditing. World Essays Journal, 1, 85-93.

[5] Pasşu, A.M. (2012) Theoretical Considerations on the Influence of Ethical Principles on Audit Quality, between Objectivity and Responsibility of the Accounting Profession. CES Working Papers, 4, 795-808.

[6] Shaw, W.H. (2008) Business Ethics. 6th Edition, Thompso Wadsworth, Belmont, CA.

[7] Al Qtaish, H.F., Baker, A.M. and Othman, O.H. (2014) The Ethical Rules of Auditing and the Impact of Compliance with the Ethical Rules on Auditing Quality. International Journal of Research and Reviews in Applied Sciences, 18, 1.

[8] http://www.e-quran.com/language/english /English 4/default.html

[9] http://www.dar-us-salam.com/TheNobleQuran

[10] Jamieson, D. and Gellermann, W. (2014) Values, Ethics, and OD Practice. The NTL handbook of Organization Development and Change, 45-65. https://doi.org/10.1002/9781118836170.ch3

[11] Rong, S.M.H. (2011) Ethical Consciousness in Auditing: A Comparison of Students and Employees.

[12] Pavel, T. and Encontro, M. (2012) The Enron Scandal. Chalmers University of Technology Financial Risk, Göteborg.

[13] Robinson, M. (2012) Enron, Study Guide. TimeLine Theatre Company. http://fliphtml5.com/ltyr/abvv/basic

[14] Benston, G.J. and Hartgraves, A.L. (2002) Enron: What Happened and What We Can Learn From It. Journal of Accounting and Public Policy, 21, 105-127. https://doi.org/10.1016/S0278-4254(02)00042-X

[15] Pha, A. (2010) Enron: Capitalism in a Nutshell. New Age Publishers, Australia.

[16] Oktik, Ş., Karaosmanoğlu, K., Eltez, A. and Benli, T. (2015) Güneş-Elektrik Enerjisi Dönüşüm Sistemlerinin Anket Değerlendirmeleri.

[17] Gordon, J.N. (2002) What Enron Means for the Management and Control of the Modern Business Corporation: Some Initial Reflections. The University of Chicago Law Review, 69, 1233-1250. https://doi.org/10.2307/1600646

[18] Benli, T., Yıldıray, K., Karaosmanoğlu, K. and Hız, G. (2013) A Field Study on the Determination of the Credit Card Users' Awareness of the Products/Services Offered with Credit Cards: Turkey Case. International Journal of Business and Management, 8, 13-29. 
[19] Jennings, M.M. (2002) Where Was the Audit Committee? Internal Auditing, 17, 42-45.

[20] Tonge, A., Greer, L. and Lawton, A. (2003) The Enron Story: You Can Fool Some of the People Some of the Time. Business Ethics: A European Review, 12, 4-22. https://doi.org/10.1111/1467-8608.00301

[21] Moncarz, E.S., Moncarz, R., Cabello, A. and Moncarz, B. (2006) The Rise and Collapse of Enron: Financial Innovation, Errors and Lessons. Contaduría y Administración, 17-37.

[22] Bryce, R. (2003) Pipe Dreams: Greed, Ego, and the Death of Enron. Public Affairs, New York.

[23] Ulusoy, T. (2010) İMKB Endeks Öngörüsü İçin İleri Beslemeli Ağ Mimarisine Sahip Yapay Sinir Ağı Modellemesi, Uluslararası İktisadive İdariİncelemeler Dergisi, Sayı, 5, 21-40.

[24] Erdoğan, M. (2012) VUK-TFRS Geçiş Sürecinde Üniversitelerde Denetim Eğitimve Öğretim Döngüsü Önerisive Web Tabanlı Bir Yazılımile Denetim Uygulaması. Dünya Sürekli Denetimve Raporlama Sempozyumu, Malatya, 3-4 May 2012, 24.

[25] G20/OECD Principles of Corporate Governance OECD Report to G20 Finance Ministers and Central Bank Governors September 2015.

[26] Mcclain, G. (2013) The Impact of Product Differentiation on the Collapse of Arthur Andersen. The Journal of Business Inquiry, 12, 1-14.

[27] Coates, J.C. (2007) The Goals and Promise of the Sarbanes-Oxley Act. The Journal of Economic Perspectives, 21, 91-116. https://doi.org/10.1257/jep.21.1.91

[28] Shakespeare, C. (2008) Sarbanes-Oxley Act of 2002 Give Years on: What Have We Learned. Journal of Business \& Technology Law, 3, 333-357.

[29] Sağlar, J. and Kandemir, C. (2007) Enron Olayi: Muhasebe Hilesi mi, Sistem Hatasimi? Çukurova Üniversitesi Íktisadi ve Ídari Bilimler Fakültesi Dergisi, 11, 20-39.

[30] Zulauf, L. and Grierson, P. (2011) Enron: The Good, the Bad, the Lessons. International Business \& Economics Research Journal, 1, 49-68. https://doi.org/10.19030/iber.v1i11.3998

[31] Dharan, B.G. and Bufkins, W.R. (2008) Red Flags in Enron's Reporting of Revenues and Key Financial Measures.

[32] Benli, T. and Kizgin, Y. (2013) The Examining of GSM Operators' Customer Complaint Management (CCM) Applications in Turkey with Discriminant Analysis. International Journal of Business and Management, 8, 1-17.

[33] Erdoğan, M. (2002) Finansal Muhasebe (Yöneticilerin Karar Verme Aracı Olarak). Beta Basın Yayım Dağıtım A.Ş., İstanbul.

[34] Felo, A.J., Mahoney, D.P. and Solieri, S.A. (2002) New Accountability for Corporate Audit Committees. Strategic Finance, 83, 52-56.

[35] Gwarzo, M. (2015) Corporate Governance and Stock Market Development. Bayero University Kano, Securities and Exchange Commission, Director General, Secnigeria, Abuja.

[36] Ulusoy, T. (2011) Financial Power Analysis of Countries: Transmitters (Adsorbents), Setters and Unresistants. African Journal of Business Management, 5, 9087-9105. 
Submit or recommend next manuscript to OALib Journal and we will provide best service for you:

- Publication frequency: Monthly

- 9 subject areas of science, technology and medicine

- Fair and rigorous peer-review system

- Fast publication process

- Article promotion in various social networking sites (LinkedIn, Facebook, Twitter, etc.)

- Maximum dissemination of your research work

Submit Your Paper Online: Click Here to Submit

Or Contact service@oalib.com 